\title{
HEAVY METAL PHYTOREMEDIATION POTENTIAL OF PLANT SPECIES IN A MANGROVE ECOSYSTEM IN PATTANI BAY, THAILAND
}

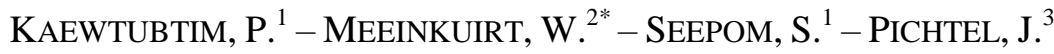 \\ ${ }^{1}$ Department of Science, Faculty of Science and Technology, Prince of Songkla University \\ Pattani Campus, Pattani 94000, Thailand \\ ${ }^{2}$ Mahidol University, Nakhonsawan Campus, Nakhonsawan 60130, Thailand \\ ${ }^{3}$ Department of Natural Resources and Environmental Management, Ball State University \\ Muncie, IN USA 47306 \\ (phone: +66-9-10240808) \\ *Corresponding author \\ e-mail: phytoplankton8@gmail.com \\ (Received $6^{\text {th }}$ Nov 2015; accepted $16^{\text {th }}$ Jan 2016)
}

\begin{abstract}
In a mangrove forest in Pattani Bay, Thailand, rhizosphere soil and leaf, stem and root tissue from various plant species were tested for concentrations of $\mathrm{Cd}, \mathrm{Cr}, \mathrm{Cu}, \mathrm{Mn}, \mathrm{Ni}, \mathrm{Pb}$ and $\mathrm{Zn}$. Of these metals, $\mathrm{Pb}$ concentrations in the mangrove sediment were somewhat elevated. Mn occurred in highest concentrations in tissue of all mangrove species whereas $\mathrm{Cd}$ contents were lowest. Both sediment physicochemical properties (e.g., $\mathrm{pH}, \mathrm{EC}$, redox potential) and plant species characteristics have likely influenced metal concentrations in plant tissue. Several mangrove species fit the criteria for excluder plants as they accumulated metals mainly in roots, with a resultant translocation factor (TF) $<1$ and a bioconcentration factor $(\mathrm{BCF})>1$. These include Cyperus involucratus for $\mathrm{Cu}$, Ipomoea pes-caprae for $\mathrm{Zn}$, Typha angustifolia for $\mathrm{Mn}$, and Phragmites karka for $\mathrm{Pb}$. Furthermore, some species have accumulator potential, as metals accumulated in aboveground biomass (leaves and stem), and have TF > 1 and $\mathrm{BCF}>1$; however, these species (e.g., Thespesia populnea for $\mathrm{Ni}$ and C. involucratus for $\mathrm{Cr}$ ) did not accumulate metals to the extent that they fit the criteria for hyperaccumulators. Continued investigation of metals in sediment and plant organs must be carried out to determine additional species suitable for phytoremediation, and to ensure healthy food chains in coastal ecosystems.
\end{abstract}

Keywords: phytoremediation, mangrove, Pattani Bay, heavy metals

\section{Introduction}

Mangrove forests are among the most biologically productive ecosystems worldwide, and comprise an important component of both coastal and marine ecosystems (Sandiyan and Kathiresan, 2012; Sandiyan and Thiyagesan, 2010). Mangroves are located primarily in tropical and sub-tropical zones (Peters et al., 1997; Moreira et al., 2013). These unique forests serve as nurseries for myriad aquatic fauna; they are critical habitats for a wide spectrum of biota including fish, crustaceans and other macro- and microfauna comprising the food web.

The root systems of mangrove trees reduce soil erosion and help stabilize adjacent coastal landforms (Harty, 1997). Moreover, it has been documented that mangrove sediments act as a sink for immobilization of metals from anthropogenic sources which enter local ecosystems (Peters et al., 1997; Tam and Wong, 1997). Metals occurring in mangrove ecosystems are adsorbed to surfaces of clay and fine silt, entrapped within the lattice structure of silicate clays, adsorbed to Fe and Mn oxides (Harbison, 1986), and 
precipitate as sulphides. In addition, metals can become immobilized within the biomass of rhizosphere microorganisms.

For decades phytoremediation technology has proven successful in treating a range of soil contaminants (Ghosh and Singh, 2005). Certain plants have the ability to uptake and accumulate metallic contaminants via the root system and store them in various plant compartments (Tangahu et al., 2011). According to Baker (1981), plants considered for phytoremediation embrace three key groups based on physiological mechanism: excluders (as employed in phytostabilization), accumulators (for phytoextraction), and indicators. Excluders are those plants that restrict contaminant uptake and accumulation, while accumulators translocate contaminants from roots to aboveground biomass. Indicator plants control the movement of contaminants from roots to shoots; therefore, the concentration of metal in the parent soil is reflected by a proportional concentration in the shoots.

Recent studies have documented the incidence and severity of sediment contamination by heavy metals in mangrove ecosystems (Anouti, 2014; Ratheesh Kumar et al., 2010). Contaminants are released via industrial activities and ultimately enter aquatic ecosystems (Ratheesh Kumar et al., 2010). The primary contaminant metals are $\mathrm{Cu}, \mathrm{Mn}, \mathrm{Ni}, \mathrm{Zn}, \mathrm{Pb}, \mathrm{Cd}$, and $\mathrm{As}$, which have been detected in significant concentrations in coastal and inshore waters (Kapi et al., 2011; Machado et al., 2002).

Pattani Bay is located along the coast of the Gulf of Thailand, Pattani Province. The bay provides critical habitat for many macroalgal and seagrass species (Hajisamae et al., 2006; Ruangchuay et al., 2007). Some species cultivated in the bay, such as Gracilaria fisheri and G. tenuistipitata, are important local foods as well as products for overseas export (Ruangchuay et al., 2007). The coastal zone also contains large expanses of sandy and muddy sediments important for clam farming and local fisheries (Swennen et al., 2001).

Several local industries including mining, cement manufacture, ship construction, and food processing have, in recent decades, released a suite of heavy metals into Pattani Bay (Cheewasedtham et al., 2003). As a result, mangrove sediments may contain elevated concentrations of metallic contaminants. Recent reports indicate that the Pattani Bay region contains high concentrations of $\mathrm{Pb}$ and $\mathrm{As}$ and exceeds the soil quality standards of the United States Environmental Protection Agency for residential areas (> 400 and $4 \mathrm{mg} \mathrm{kg}^{-1}$ for $\mathrm{Pb}$ and As, respectively) (Sowana et al., 2011). Industrial activities and domestic wastes are believed to be the main causes of heavy metal contamination in seawater of the bay, which adversely affects aquatic organisms, for example the blood clam (Anadara granosa), an important cultured benthic organism in this area, via accumulation of metals (Suwanjarat et al., 2009).

A number of innovative technologies are available for the removal or immobilization of heavy metals from soil and sediments including soil flushing, electrokinetic remediation, chemical oxidation/reduction, and vitrification. Many of these technologies, however, are energy-intensive, have substantial start-up and operational costs, require specialized training, and require the use of hazardous chemicals (Pichtel, 2007).

Phytoremediation is a relatively low-cost and environmentally benign technology which can minimize concentrations of contaminant heavy metals that persist in soil and sediment. Specifically, phytoextraction (i.e., metal uptake and removal) and phytostabilization (metal immobilization in or near the rhizosphere) are applicable technologies for use in mangrove forests (Gohre and Paszkowski, 2006; Paz-Alberto and Sigua, 2013). Some researchers have indicated that phytostabilization is, to some 
extent, more reliable for remediation of metal contamination as it prevents the release of secondary contaminants that may occur during planting (Singh and Tripathi, 2007). Rhizophora mucronata is considered one of the most effective excluder mangrove trees - it has been documented to have stabilized $\mathrm{Cu}, \mathrm{Cd}, \mathrm{Cr}, \mathrm{Fe}, \mathrm{Mg}, \mathrm{Ni}, \mathrm{Pb}$ and $\mathrm{Zn}$, primarily in the root (Panfili et al., 2005; Pahalawattaarachchi et al., 2009). However, there are no reports on the use of mangroves for phytoremediation in Thailand.

The identification of effective phytoremediation species in Thailand's mangrove forests is especially urgent, as there are concerns of significant losses of mangrove communities due to anthropogenic activities such as human settlement, water transportation, and agricultural and aquaculture activities (Aksornkoae, 1993; Plathong and Sitthirach, 1998). It is estimated that mangrove forests along Thailand's east coast have been reduced by at least $10 \%$ over the past five decades (Thampanya et al., 2006).

The current report describes the first investigation of the potential of mangrove plants for phytoremediation in Thailand. Different parts of the mangrove plant were assessed for heavy metal uptake and accumulation; these data were compared with corresponding concentrations in sediments. Plant parts were subsequently classified for their potential for phytoremediation of heavy metals in contaminated mangrove ecosystems.

\section{Materials and Methods}

\section{Site Description}

Pattani Bay is located on the eastern Gulf of southern Thailand (Fig. 1). This semienclosed estuarine bay, measuring approximately $74 \mathrm{~km}^{2}$, receives input from two major rivers, the Pattani and the Yaring (Hajisamae et al., 2006; Suwanjarat et al., 2009; Swennen et al., 2001). The water regime of the bay is a complex system which receives significant influences from tidal inputs and the tropical monsoon climate as well as surface runoff and drainage from the two rivers. Water depth in the bay ranges from 0.2 to $1.5 \mathrm{~m}$ with a maximum $5 \mathrm{~m}$ depth at the mouth of the bay. Cumulative annual rainfall and average annual temperature at Pattani Bay in 2014 were $2008.5 \mathrm{~mm}$ and $27.5{ }^{\circ} \mathrm{C}$, respectively.

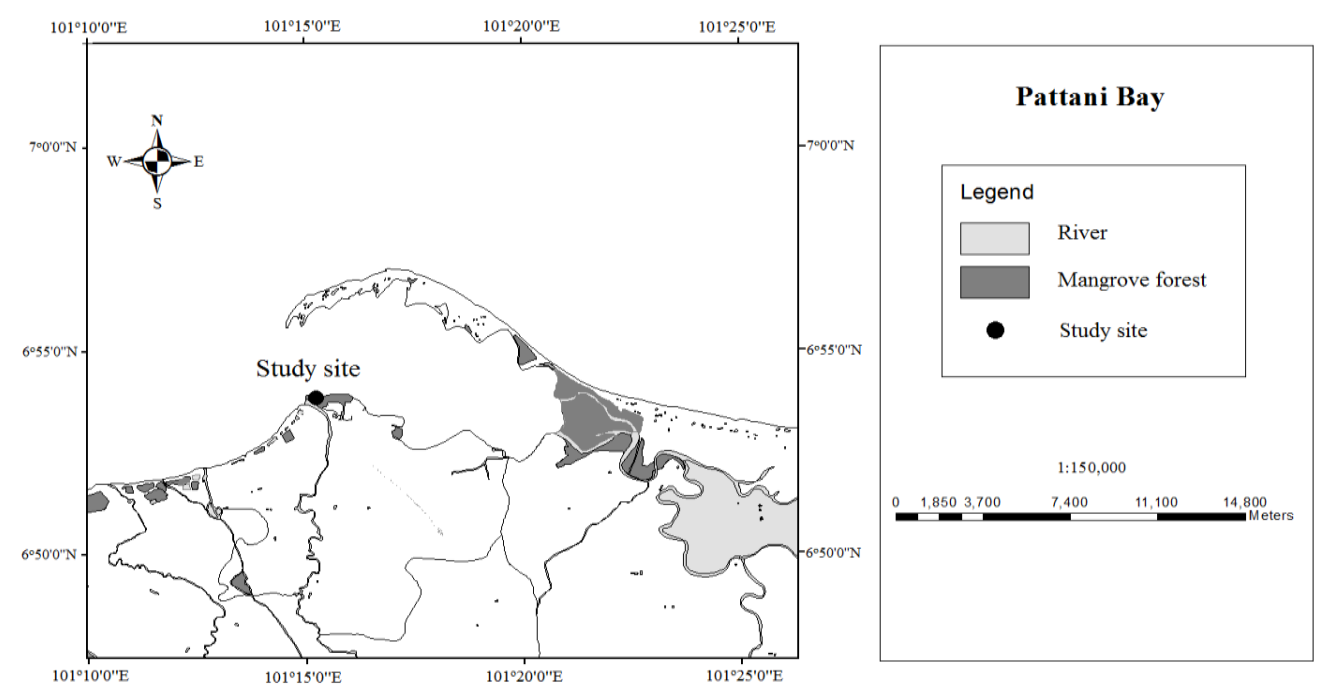

Figure 1. Map of study site, Pattani Bay, Thailand 


\section{Plant sampling}

The sampling site, considered representative of a mangrove ecosystem, measures approximately 40 ha and is located near the mouth of the bay (Fig. 1).

In the study area, dominant mangrove plants were identified and used for tissue analysis and for collection of rhizosphere soil. Three plants from each species were collected. Plant tissue was returned to the laboratory and stored in a plant press. Tentative identification of species was via Aksornkoae et al. (1992) and later confirmed by the Department of Forestry, Thailand.

\section{Physicochemical properties of soil material}

Fifteen samples of surface sediments $(0-15 \mathrm{~cm}$ depth) were collected near the rhizosphere of each mangrove plant. Samples were mixed in the field to create a composite sample. Samples were returned to the laboratory, oven-dried at $80^{\circ} \mathrm{C}$, ground using an agate mortar and pestle, and sieved through a 2-mm mesh nylon sieve. Samples were stored in plastic bags until analysis.

Sediment $\mathrm{pH}$ was analyzed in a 1:5 suspension of soil to deionized (DI) water using a $\mathrm{pH}$ meter (Accumet ${ }^{\circledR}$ AP115 pH meter). Electrical conductivity (EC) was analyzed in sediment extracts (1:5) using an EC meter (Hanna instruments; HI 993310). Sediment organic matter content was determined by the Walkley-Black titration method (Walkley and Black, 1934). Cation exchange capacity (CEC) was measured by leaching with $1 \mathrm{~N}$ ammonium acetate buffered to $\mathrm{pH} 7.0$ (Sparks, 1996). Salinity was determined by a salinometer. Texture was determined by the hydrometer method (Allen et al., 1974). Total $\mathrm{N}$ was determined by the Kjedahal method (Black, 1965), extractable P using Mehlich-3 (Bray and Kurtz, 1945), and extractable K by ICP-OES after extraction with $\mathrm{NH}_{4} \mathrm{OAc}(\mathrm{pH} 7.0)$ (Sparks, 1996).

Total metal $(\mathrm{Cd}, \mathrm{Cr}, \mathrm{Cu}, \mathrm{Mn}, \mathrm{Ni}, \mathrm{Pb}, \mathrm{Zn})$ concentrations were determined by either FAAS or GF-AAS (APHA/AWWA/WEF, 2005), depending on metal concentration in the samples, after acid digestion in a microwave digestion system (ETHOS One; Milestone Inc., Shelton, CT, USA). Extractable metals were recovered using 0.5 M diethylene triamine pentaacetic acid (DTPA), then determined by flame atomic absorption spectrophotometry (FAAS) or graphite furnace atomic absorption spectrophotometry (GF-AAS) (APHA/AWWA/WEF, 2005). An appropriate sediment and plant tissue standard reference material (NIST SRM ${ }^{\circledR}$ 2710a Montana soil, and NIST SRM ${ }^{\circledR} 1515$ apple leaves, respectively) and a reagent blank (Merck ${ }^{\circledR}$; trace metal grade) were used to check the quality and metrological traceability of the samples and to validate analytical methods.

\section{Plant sampling and heavy metals analyses}

Leaves, stems and roots were cut from selected locations on each plant using stainless steel scissors. All plant parts were thoroughly washed with tap water and phosphate-free soap in a plastic container, then rinsed several times to remove any attached soil and soap. Finally, plant tissue was rinsed twice with DI water. Leaf, stem and root tissue was oven-dried at $80{ }^{\circ} \mathrm{C}$ for $2-3$ days. Tissue was subsequently ground to a fine powder and sieved through a 2-mm mesh nylon sieve. One-half $\mathrm{g}$ of plant tissue was placed in each vessel tube with conc. $70 \% \mathrm{HNO}_{3}$ and $37 \% \mathrm{HCl}$ for microwave digestion (ETHOS One; Milestones Inc.). The digested samples were tested for concentration of $\mathrm{Cd}, \mathrm{Cr}, \mathrm{Cu}, \mathrm{Mn}, \mathrm{Ni}, \mathrm{Pb}$ and $\mathrm{Zn}$ by either FAAS or GF-AAS. 


\section{Data analyses}

The translocation factor (TF) for each plant was calculated by dividing metal concentration in the shoot by metal concentration in the root. A TF value $>1$ indicates the plant's potential to translocate metal effectively from root to shoot (Rezvani and Zaefarian, 2011). The equation was as follows:

$$
\begin{aligned}
& \mathrm{TF}_{\text {leaf }}=C_{\text {leaf }} / C_{\text {root }} \\
& \mathrm{TF}_{\text {stem }}=C_{\text {stem }} / C_{\text {root }}
\end{aligned}
$$

where $C_{\text {leaf }}, C_{\text {stem }}$ and $C_{\text {root }}$ are the metal concentrations in leaf, stem and root, respectively.

The bioconcentration factor $(\mathrm{BCF})$ is defined as the ratio of metal concentration in the shoot to the extractable metal concentration in the rhizosphere soil (Rezvani and Zaefarian, 2011). This value reflects the progressive accumulation of metal in the plant (Branquinho et al., 2007). The bioconcentration factor for metals was calculated as follows:

$$
\begin{aligned}
\mathrm{BCF}_{\text {leaf }} & =C_{\text {leaf }} / C_{\text {sediment (extractable metal) }} \\
\mathrm{BCF}_{\text {stem }} & =C_{\text {stem }} / C_{\text {sediment (extractable metal) }} \\
\mathrm{BCF}_{\text {root }} & =C_{\text {root }} / C_{\text {sediment (extractable metal) }}
\end{aligned}
$$

where $C_{\text {leaf }}, C_{\text {stem }}$ and $C_{\text {root }}$ are the metal concentrations in leaf, stem and root, respectively, and $C_{\text {sediment }}$ is the metal concentration in the sediment.

Data were expressed as mean+standard deviation (SD). Analysis of variance (One way ANOVA; SPSS version 18.0) was used to assess differences in plant metal uptake characteristics.

\section{Results and Discussion}

\section{Sediment characteristics in mangrove forest}

The $\mathrm{pH}$ of the mangrove sediments was slightly alkaline ( $\mathrm{pH}$ 7.3) (Table 1). Sediment EC was relatively high $\left(5.5 \mathrm{mS} \mathrm{cm}^{-1}\right)$, which reflects the influence of seawater. Concentrations of total $\mathrm{N}$ and extractable $\mathrm{P}$ and $\mathrm{K}$ were relatively low; however, values were still within the ranges found for mangrove sediments in other studies (Sowana et al., 2011). Soil OM content was 2.3\%. High concentrations of soil OM have been measured in mangrove forests of Pattani Bay, with maximum values reaching 4.5\% (Sowana et al., 2011). The relatively high organic matter content in the mangrove sediment arises from decomposition of plant material and other detritus of both terrestrial and marine origin (Marchand et al., 2011). Soil texture was loam; however, other mangrove sediments worldwide are known to contain high clay and silt content (Stokes and Harris, 2015; Zhang et al., 2013). 
Table 1. Selected physicochemical properties of the mangrove sediment

\begin{tabular}{lc}
\hline Parameter & Sediment \\
\hline $\mathrm{pH}$ & $7.3 \pm 0.2$ \\
$\mathrm{EC}\left(\mathrm{mS} \mathrm{cm}^{-1}\right)$ & $5.5 \pm 2.9$ \\
$\mathrm{CEC}\left(\mathrm{cmol}^{-}+\mathrm{kg}^{-1}\right)$ & $11.6 \pm 2.5$ \\
$\mathrm{OM}(\%)$ & $2.3 \pm 0.6$ \\
Total N $(\%)$ & $0.1 \pm 0.0$ \\
Ext $\mathrm{P}\left(\mathrm{mg} \mathrm{kg}^{-1}\right)$ & $880.0 \pm 100.1$ \\
Ext K $\left(\mathrm{mg} \mathrm{kg}^{-1}\right)$ & $886.0 \pm 105.8$ \\
Salinity $(\mathrm{ppt})$ & $16.4 \pm 5.9$ \\
Soil texture & Loam \\
\hline
\end{tabular}

$\mathrm{EC}=$ electrical conductivity, $\mathrm{CEC}=$ cation exchange capacity, $\mathrm{OM}=$ organic matter, $\mathrm{Ext}=$ extractable

Sediment metal concentrations (Table 2) were similar to or lower than those recorded in studies of metal-contaminated sediments from other locations worldwide ( $\mathrm{Xu}$ et al., 2015; Banerjee et al., 2012; Chakraborty et al., 2012). Concentrations of $\mathrm{Cd}, \mathrm{Cr}, \mathrm{Cu}$, $\mathrm{Mn}, \mathrm{Ni}$ and $\mathrm{Zn}$ were within world average concentrations for sediments as proposed by Turekian and Wedepohl (1961). However, sediment $\mathrm{Pb}$ concentration was $47 \mathrm{mg} \mathrm{kg}^{-1}$, which is slightly elevated and believed to arise from industrial activities located nearby.

Table 2. Total and extractable forms of metals in mangrove sediments of selected coastal zones

\begin{tabular}{|c|c|c|c|c|}
\hline Metal & $\begin{array}{c}\text { Pattani Bay } \\
\text { (Present study) }\end{array}$ & $\begin{array}{c}\text { Shenzhen City } \\
\text { (Xu et al., } \\
\text { 2015) } \\
\end{array}$ & $\begin{array}{c}\text { Ganges } \\
\text { (Banerjee et al., } \\
\text { 2012) } \\
\end{array}$ & $\begin{array}{c}\text { Godavari } \\
\text { (Chakraborty et al., } \\
\text { 2012) } \\
\end{array}$ \\
\hline $\mathrm{Cd}\left(\mathrm{mg} \mathrm{kg}^{-1}\right)$ & $0.2 \pm 0.1$ & $\mathrm{BDL}^{1}$ & 2.0 & 24.8 \\
\hline $\mathrm{Cr}\left(\mathrm{mg} \mathrm{kg}^{-1}\right)$ & $58.3 \pm 7.5$ & $33.8 \pm 16.4$ & 40.1 & 71.2 \\
\hline $\mathrm{Cu}\left(\mathrm{mg} \mathrm{kg}^{-1}\right)$ & $22.1 \pm 1.7$ & $52.9 \pm 29.1$ & 21.6 & 103.4 \\
\hline $\operatorname{Mn}\left(\mathrm{mg} \mathrm{kg}^{-1}\right)$ & $101.4 \pm 18.3$ & $331.0 \pm 133.0$ & 502.4 & - \\
\hline $\mathrm{Ni}\left(\mathrm{mg} \mathrm{kg}^{-1}\right)$ & $16.9 \pm 8.7$ & $21.8 \pm 8.0$ & 34.0 & 63.8 \\
\hline $\mathrm{Pb}\left(\mathrm{mg} \mathrm{kg}^{-1}\right)$ & $47.3 \pm 7.1$ & $48.3 \pm 17.8$ & 23.5 & 424.0 \\
\hline $\mathrm{Zn}\left(\mathrm{mg} \mathrm{kg}^{-1}\right)$ & $26.6 \pm 3.9$ & $182.0 \pm 94.1$ & 53.4 & 3876.7 \\
\hline Ext Cd $\left(\mathrm{mg} \mathrm{kg}^{-1}\right)$ & BDL & $-{ }^{2}$ & - & - \\
\hline Ext $\mathrm{Cr}\left(\mathrm{mg} \mathrm{kg}^{-1}\right)$ & $0.7 \pm 0.2$ & - & - & - \\
\hline Ext $\mathrm{Cu}\left(\mathrm{mg} \mathrm{kg}^{-1}\right)$ & $6.5 \pm 1.1$ & - & - & - \\
\hline Ext $\mathrm{Mn}\left(\mathrm{mg} \mathrm{kg}^{-1}\right)$ & $22.9 \pm 9.4$ & - & - & - \\
\hline Ext Ni $\left(\mathrm{mg} \mathrm{kg}^{-1}\right)$ & $2.9 \pm 0.9$ & - & - & - \\
\hline Ext $\mathrm{Pb}\left(\mathrm{mg} \mathrm{kg}^{-1}\right)$ & $7.5 \pm 2.3$ & - & - & - \\
\hline Ext Zn (mg kg-1) & $2.3 \pm 0.2$ & - & - & - \\
\hline
\end{tabular}

${ }^{1}=$ BDL $=$ below detectable limits.

$2=$ Data not available. 


\section{Plant survey in the study site}

Based on field observations the predominant mangrove and mangrove associated species show a remarkable diversity in the study area at Pattani Bay. A total of 18 species were identified and grouped based on plant habits as follows: groundcover (Wedelia biflora, Sesuvium portulacastrum, Ipomoea pes-caprae, Phyla nodiflora); climbing plants (Derris trifoliata, Passiflora foetida); grass plants (Dichanthium caricosum, Phragmites karka), shrub (Avicennia marina, Acanthus ebracteatus, A. alba, Pluchea indica,); trees (Thespesia populnea, Rhizophora mucronata); aquatic plants (Typha angustifolia, Eleocharis dulcis, Cyperus involucratus), and pteridophyte plants (Acrostichum aureum). Only Avicennia spp. and $R$. mucronata were classified as mangrove species, while others were mangrove-associated species. The mangrove shrubs are the primary ecotone species in mangrove ecosystems and serve as habitat for both terrestrial and marine organisms. Wedelia biflora and $S$. portulacastrum were the predominant groundcover species, while $A$. marina and $P$. indica were the dominant shrub species. Avicennia marina was reported to grow abundantly in several mangrove forests in Pattani province (Plathong and Sitthirach, 1998), while Hajisamae and Yeesin (2014) found that Rhizophora spp. was the dominant mangrove tree species occurring in coastal zones of Pattani Bay. However, many mangrove species such as Rhizophora mucronata, $R$. apiculata, Sonneratia alba, $A$. alba, A. officinalis, Bruguiera gymnorhiza, B. cylindrical, Xylocarpus moluccensis, Acanthus ilicifolius, Excoecaria agallocha and Nypa fruticans were found to be dominant nearby (Hajisamae et al., 2006).

\section{Heavy metal content and phytoremediation potential of mangrove species}

Each mangrove species accumulated metals at different rates $(p<0.05)$, depending on both species and plant organ (Madejón et al., 2003; Marschner, 1986) (Table 3).

Table 3. Metal concentrations in mangrove plant parts. $(n=3)$

\begin{tabular}{|c|c|c|c|c|c|c|c|c|}
\hline \multirow{2}{*}{ Plant } & \multirow{2}{*}{ Tissue } & \multicolumn{7}{|c|}{ Metal concentration $\left(\mathrm{mg} \mathrm{kg}^{-1}\right)$} \\
\hline & & $\mathbf{C u}$ & Zn & $\mathbf{N i}$ & Mn & $\mathrm{Cr}$ & Cd & $\mathbf{P b}$ \\
\hline \multirow[t]{3}{*}{ W. biflora } & Stem & $8.1 \pm 0.6^{b}$ & $20.0 \pm 0.8^{b}$ & $17.0 \pm 2.9^{\mathrm{a}}$ & $11.3 \pm 1.8^{\mathrm{a}}$ & $1.8 \pm 0.1^{\mathrm{a}}$ & $0.4 \pm 0.0^{\mathrm{b}}$ & $15.8 \pm 0.3^{b}$ \\
\hline & Leaf & $8.6 \pm 0.3^{\mathrm{b}}$ & $14.0 \pm 2.0^{\mathrm{a}}$ & $14.0 \pm 4.4^{\mathrm{a}}$ & $26.0 \pm 4.0^{\mathrm{c}}$ & $1.1 \pm 0.1^{\mathrm{a}}$ & $0.4 \pm 0.0^{\mathrm{c}}$ & $4.1 \pm 0.3^{\mathrm{a}}$ \\
\hline & Root & $16.2 \pm 0.0^{\mathrm{b}}$ & $19.0 \pm 1.5^{\mathrm{ab}}$ & $11.0 \pm 0.4^{\mathrm{a}}$ & $25.7 \pm 3.0^{\mathrm{b}}$ & $1.0 \pm 0.0^{\mathrm{a}}$ & $0.3 \pm 0.0^{\mathrm{b}}$ & $7.9 \pm 0.3^{\mathrm{a}}$ \\
\hline \multirow[t]{3}{*}{ S. portulacastrum } & Stem & $17.3 \pm 2.1^{\mathrm{d}}$ & $21.7 \pm 0.3^{\mathrm{b}}$ & $40.2 \pm 1.2^{\mathrm{c}}$ & $9.4 \pm 0.0^{\mathrm{a}}$ & $0.6 \pm 0.1^{\mathrm{a}}$ & $0.2 \pm 0.1^{\mathrm{b}}$ & $6.9 \pm 0.5^{\mathrm{a}}$ \\
\hline & Leaf & $8.3 \pm 0.3^{\mathrm{b}}$ & $19.0 \pm 3.3^{\mathrm{b}}$ & $32.8 \pm 8.2^{\mathrm{c}}$ & $12.8 \pm 1.7^{\mathrm{b}}$ & $0.6 \pm 0.0^{\mathrm{a}}$ & $0.3 \pm 0.0^{\mathrm{b}}$ & $3.6 \pm 0.2^{\mathrm{a}}$ \\
\hline & Root & $8.3 \pm 0.7^{\mathrm{a}}$ & $17.1 \pm 0.6^{\mathrm{a}}$ & $30.6 \pm 2.3^{\mathrm{c}}$ & $19.5 \pm 1.7^{\mathrm{a}}$ & $0.6 \pm 0.0^{\mathrm{a}}$ & $0.3 \pm 0.1^{\mathrm{b}}$ & $17.0 \pm 3.6^{\mathrm{b}}$ \\
\hline \multirow[t]{3}{*}{ I. pes-caprae } & Stem & $3.8 \pm 0.1^{\mathrm{a}}$ & $8.6 \pm 0.4^{\mathrm{a}}$ & $22.9 \pm 1.1^{\mathrm{b}}$ & $22.9 \pm 1.1^{\mathrm{b}}$ & $31.4 \pm 5.7^{\mathrm{c}}$ & $0.6 \pm 0.1^{\mathrm{c}}$ & $17.7 \pm 1.2^{\mathrm{b}}$ \\
\hline & Leaf & $5.0 \pm 0.5^{\mathrm{a}}$ & $14.4 \pm 5.3^{\mathrm{a}}$ & $25.1 \pm 0.7^{\mathrm{b}}$ & $38.5 \pm 5.1^{\mathrm{d}}$ & $37.6 \pm 1.4^{\mathrm{c}}$ & $0.6 \pm 0.0^{\mathrm{d}}$ & $25.9 \pm 1.9^{c}$ \\
\hline & Root & $20.8 \pm 0.7^{\mathrm{c}}$ & $78.1 \pm 1.3^{\mathrm{c}}$ & $52.9 \pm 7.4^{\mathrm{d}}$ & $236.2 \pm 21.4^{\mathrm{c}}$ & $107.1 \pm 4.0^{\mathrm{c}}$ & $0.5 \pm 0.1^{\mathrm{c}}$ & $4.4 \pm 0.6^{\mathrm{a}}$ \\
\hline \multirow[t]{3}{*}{ P. nodiflora } & Stem & $12.8 \pm 0.6^{\mathrm{c}}$ & $22.2 \pm 0.1^{\mathrm{b}}$ & $23.6 \pm 3.8^{\mathrm{b}}$ & $10.7 \pm 0.5^{\mathrm{a}}$ & $13.0 \pm 1.5^{\mathrm{b}}$ & $0.1 \pm 0.0^{\mathrm{a}}$ & $\mathrm{BDL}^{1}$ \\
\hline & Leaf & $7.8 \pm 0.6^{\mathrm{b}}$ & $17.2 \pm 0.1^{\mathrm{a}}$ & $18.6 \pm 3.8^{\mathrm{ab}}$ & $5.7 \pm 0.5^{\mathrm{a}}$ & $8.0 \pm 1.5^{b}$ & $0.1 \pm 0.0^{\mathrm{a}}$ & $3.1 \pm 0.1^{\mathrm{a}}$ \\
\hline & Root & $22.5 \pm 1.8^{\mathrm{d}}$ & $20.7 \pm 0.1^{\mathrm{b}}$ & $23.1 \pm 2.3^{\mathrm{b}}$ & $23.1 \pm 2.3^{\mathrm{a}}$ & $26.6 \pm 1.0^{\mathrm{b}}$ & $0.2 \pm 0.0^{\mathrm{a}}$ & BDL \\
\hline \multirow[t]{3}{*}{ D. trifoliata } & Stem & $13.3 \pm 1.4^{\mathrm{a}}$ & $17.5 \pm 3.0^{\mathrm{a}}$ & $26.2 \pm 1.0^{\mathrm{a}}$ & $82.4 \pm 7.0^{b}$ & $38.5 \pm 6.0^{\mathrm{a}}$ & BDL & $40.8 \pm 2.1^{b}$ \\
\hline & Leaf & $8.3 \pm 1.4^{\mathrm{a}}$ & $12.5 \pm 3.1^{\mathrm{a}}$ & $21.2 \pm 1.0^{\mathrm{b}}$ & $77.4 \pm 7.0^{\mathrm{b}}$ & $33.5 \pm 6.0^{\mathrm{b}}$ & BDL & $45.8 \pm 2.1^{\mathrm{b}}$ \\
\hline & Root & $15.1 \pm 0.2^{\mathrm{a}}$ & $14.0 \pm 1.3^{\mathrm{a}}$ & $22.5 \pm 0.5^{\mathrm{a}}$ & $8.9 \pm 0.2^{\mathrm{a}}$ & $16.8 \pm 1.5^{\mathrm{a}}$ & $0.1 \pm 0.0^{\mathrm{a}}$ & $5.2 \pm 0.1^{\mathrm{a}}$ \\
\hline \multirow[t]{3}{*}{ P. foetida } & Stem & $14.3 \pm 0.5^{\mathrm{c}}$ & $28.2 \pm 0.7^{\mathrm{b}}$ & $20.9 \pm 0.5^{\mathrm{a}}$ & $20.3 \pm 1.4^{\mathrm{a}}$ & $20.4 \pm 1.1^{\mathrm{b}}$ & $0.1 \pm 0.0$ & $27.8 \pm 0.8^{\mathrm{a}}$ \\
\hline & Leaf & $9.4 \pm 0.4^{\mathrm{b}}$ & $23.3 \pm 0.7^{\mathrm{b}}$ & $16.0 \pm 0.6^{\mathrm{a}}$ & $15.4 \pm 1.5^{\mathrm{a}}$ & $15.5 \pm 1.0^{\mathrm{a}}$ & $0.1 \pm 0.0$ & $22.9 \pm 1.0^{\mathrm{a}}$ \\
\hline & Root & $20.3 \pm 0.9^{\mathrm{b}}$ & $26.9 \pm 3.1^{\mathrm{b}}$ & $22.6 \pm 1.3^{\mathrm{a}}$ & $11.3 \pm 1.9^{\mathrm{b}}$ & $21.8 \pm 2.3^{\mathrm{b}}$ & $0.1 \pm 0.0^{\mathrm{a}}$ & $32.0 \pm 2.0^{\mathrm{b}}$ \\
\hline \multirow[t]{3}{*}{ D. caricosum } & Stem & $6.9 \pm 0.3^{\mathrm{a}}$ & $10.1 \pm 0.6^{\mathrm{a}}$ & $21.8 \pm 0.6^{\mathrm{b}}$ & $94.1 \pm 1.7^{b}$ & $22.3 \pm 0.7^{\mathrm{a}}$ & $0.2 \pm 0.0^{\mathrm{a}}$ & $11.9 \pm 1.5^{\mathrm{b}}$ \\
\hline & Leaf & $-^{2}$ & - & - & - & - & - & - \\
\hline & Root & $21.8 \pm 0.2^{\mathrm{b}}$ & $14.6 \pm 0.4^{\mathrm{a}}$ & $23.3 \pm 3.7^{\mathrm{b}}$ & $234.1 \pm 3.2^{\mathrm{b}}$ & $52.5 \pm 3.2^{\mathrm{b}}$ & $0.2 \pm 0.1^{\mathrm{a}}$ & $51.8 \pm 5.2^{\mathrm{a}}$ \\
\hline \multirow{3}{*}{ P. karka } & Stem & $10.5 \pm 3.6^{\mathrm{b}}$ & $23.1 \pm 1.2^{\mathrm{b}}$ & $18.0 \pm 1.4^{\mathrm{a}}$ & $8.6 \pm 0.4^{\mathrm{a}}$ & $20.1 \pm 4.6^{\mathrm{a}}$ & $0.3 \pm 0.1^{\mathrm{b}}$ & $9.0 \pm 0.4^{\mathrm{a}}$ \\
\hline & Leaf & $6.2 \pm 0.5$ & $29.8 \pm 1.3$ & $19.9 \pm 0.8$ & $26.1 \pm 1.3$ & $48.3 \pm 1.8$ & $0.1 \pm 0.0$ & $15.9 \pm 0.7$ \\
\hline & Root & $15.5 \pm 0.8^{\mathrm{a}}$ & $22.0 \pm 1.0^{\mathrm{b}}$ & $21.5 \pm 0.9^{\mathrm{a}}$ & $87.0 \pm 13.3^{\mathrm{a}}$ & $33.1 \pm 1.0^{\mathrm{a}}$ & $0.4 \pm 0.1^{\mathrm{b}}$ & $71.2 \pm 1.2^{\mathrm{a}}$ \\
\hline \multirow[t]{3}{*}{ A. marina } & Stem & $8.0 \pm 0.4^{b}$ & $12.9 \pm 1.2^{\mathrm{b}}$ & $18.7 \pm 4.4^{\mathrm{a}}$ & $37.3 \pm 4.7^{b}$ & $0.8 \pm 0.0^{\mathrm{a}}$ & $0.3 \pm 0.1^{\mathrm{a}}$ & $61.7 \pm 1.4^{\mathrm{c}}$ \\
\hline & Leaf & $10.8 \pm 0.9^{\mathrm{b}}$ & $11.1 \pm 0.6^{\mathrm{b}}$ & $38.3 \pm 7.4^{\mathrm{c}}$ & $224.0 \pm 20.2^{\mathrm{c}}$ & $0.4 \pm 0.1^{\mathrm{a}}$ & $0.4 \pm 0.0^{\mathrm{a}}$ & $30.3 \pm 0.3^{\mathrm{b}}$ \\
\hline & Root & $9.7 \pm 2.0^{\mathrm{b}}$ & $19.1 \pm 1.5^{\mathrm{b}}$ & $24.6 \pm 1.3^{\mathrm{b}}$ & $129.0 \pm 7.5^{\mathrm{b}}$ & $1.1 \pm 0.1^{\mathrm{b}}$ & $0.4 \pm 0.0^{\mathrm{ab}}$ & $75.7 \pm 0.5^{\mathrm{c}}$ \\
\hline A. ebracteatus & Stem & $9.9 \pm 0.9^{\mathrm{b}}$ & $18.9 \pm 1.5^{\mathrm{a}}$ & $20.0 \pm 0.8^{\mathrm{a}}$ & $47.2 \pm 3.0^{\mathrm{b}}$ & $16.0 \pm 0.8^{\mathrm{b}}$ & $0.5 \pm 0.0^{\mathrm{b}}$ & $47.3 \pm 1.0^{\mathrm{b}}$ \\
\hline
\end{tabular}




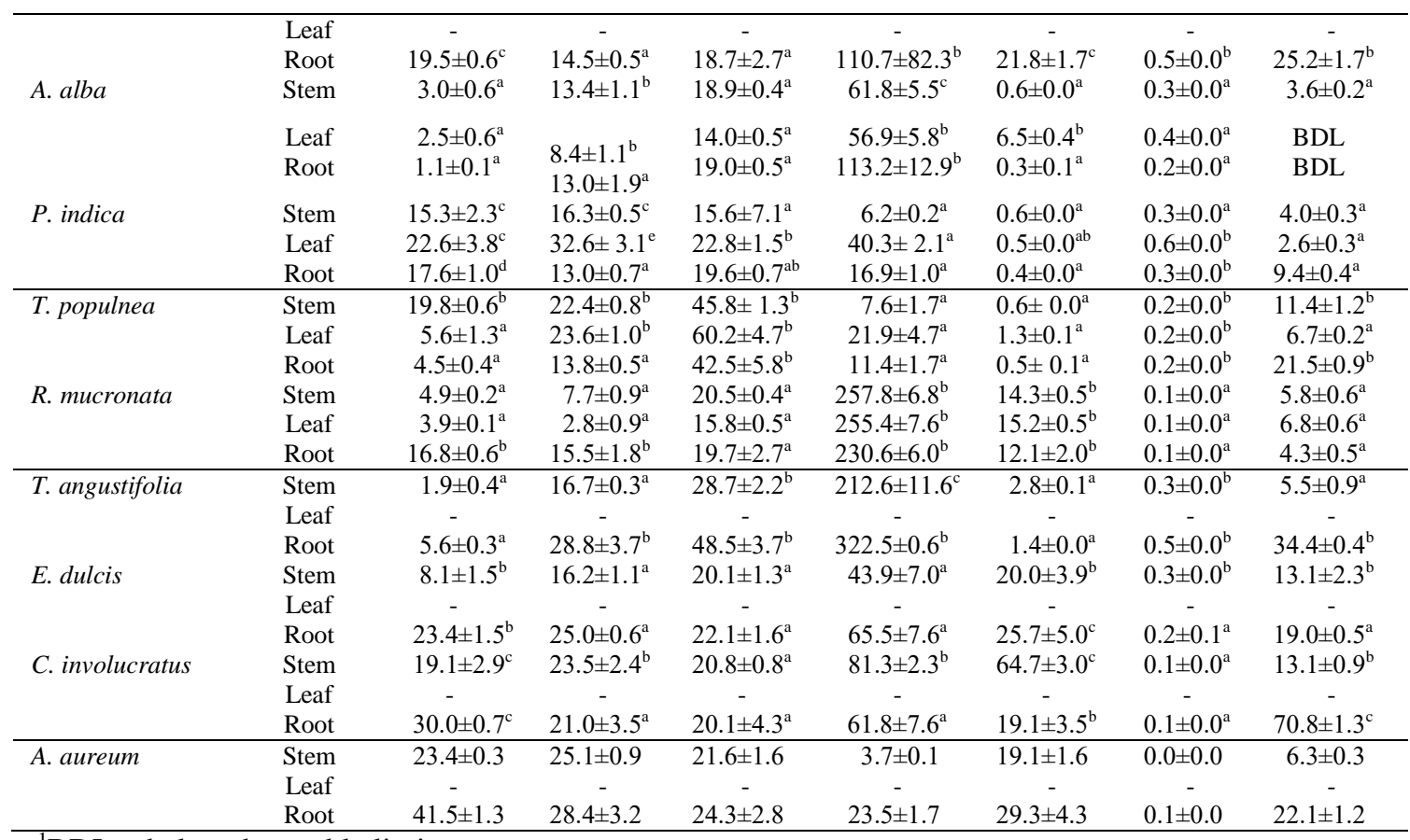

${ }^{1} \mathrm{BDL}=$ below detectable limits.

2 = Data not available.

Values followed by the same letter are not significantly different at $p<0.05$. Small letters indicate the difference of metal contents when compared between each plant organ among different plant types (ground cover, climbing plant, grass, shrub, tree, aquatic and pteridophyte species, respectively) (LSD: $p<0.05)$.

Copper in tissue ranged from 1.1 (A. alba root) to $23.4 \mathrm{mg} \mathrm{kg}^{-1}$ (E. dulcis root); $\mathrm{Zn}$ from 2.8 (R. muconata leaf) to $78 \mathrm{mg} \mathrm{kg}^{-1}$ (I. pes-caprae root); Ni from 11.0 (W. biflora root) to $60.2 \mathrm{mg} \mathrm{kg}^{-1}$ (T. populnea leaf); Mn from 5.7 (P. noniflora leaf) to $257 \mathrm{mg} \mathrm{kg}^{-1}$ (R. muconata stem); Cr from 0.4 (P. indica root) to 107 (I. pes-caprae root); Cd from $\mathrm{BDL}$ (various species and parts) to $0.6 \mathrm{mg} \mathrm{kg}^{-1}$; and $\mathrm{Pb}$ from BDL (various) to $75.7 \mathrm{mg}$ $\mathrm{kg}^{-1}$ (A. marina root) (Table 3).

The low availability of several metals (e.g., $\mathrm{Cu}, \mathrm{Ni}, \mathrm{Zn}$ ) to plants in the mangrove ecosystem may be explained by: (1) the organic content of the detritus-rich bottom sediments form complex refractory organics, which are believed to be a major cause of reduced metal bioavailability (MacFarlane et al., 2003); (2) high levels of salinity result in the formation of metal-chloride complexes of low availability for plant uptake and accumulation (Greger, 2004); (3) the nature of metals trapped by mangrove sediments -metals are adsorbed to sediments/or clay minerals either at permanent charge sites (ion exchanges sites of fine silts/clays) or at surface-hydroxyl (amphoteric) sites (Cowan et al., 1992; Harbison, 1986), resulting in low plant availability (Lacerda, 1997); (4) metals react with sulphides to form metal sulphides in the anoxic layer of the sediment. Metal sulphides tend to be highly insoluble; however, they may be partially taken up by roots and transported via the xylem (Youssef and Saenger, 1996). In mangrove surface soils, low sulphide concentrations were found $(<1 \mathrm{mM})$ along with correspondingly high redox values $(+250 \mathrm{mV}$ to $-150 \mathrm{mV}$ ), whereas low redox potentials were determined in sediments below $30 \mathrm{~cm}$ depth with correspondingly higher sulphide concentrations $(\sim 2 \mathrm{mM})$ (Lyimo et al., 2002) (5) The relatively high $\mathrm{pH}$ (7.4, Table 1) 
will result in precipitation of many metals as oxides, carbonates, etc. (Meeinkuirt et al., 2012, 2013; Pichtel, 2007; Usman et al., 2013).

Manganese was the only element that plant organs accumulated in high quantities, followed by $\mathrm{Cr}$. Cadmium and $\mathrm{Pb}$ were accumulated minimally by all plant organs. These phenomena are consistent with reports on metal behavior in mangrove sediments elsewhere (Chowdhury et al., 2015; Kim et al., 2010).

Translocation values between roots and aboveground parts (leaves and stems) ranged from 0.2-4.4 for $\mathrm{Cu}, 0.1-2.5$ for $\mathrm{Zn}, 0.4-1.6$ for $\mathrm{Ni}, 0.1-9.3$ for $\mathrm{Mn}, 0.2-4.4$ for $\mathrm{Cr}, 0.1$ 2.1 for $\mathrm{Cd}$, and 0.1-7.9 for $\mathrm{Pb}$ (Table 4). Of 217 tissue samples, $128 \mathrm{had} \mathrm{TF}$ values $<1$ and 89 had $\mathrm{TF}$ values $>1$. TF values $<1$ indicate low metal translocation to shoots. These data are consistent with results for terrestrial plants grown in other metalcontaminated soils (Meeinkuirt et al., 2012; Phaenark et al., 2009). Different plant types have markedly different physiology, which results in different translocation potential for metals (Chen et al., 2005)

High metal concentrations in roots combined with TF values $<1$ indicate the potential of the plant for well-balanced metal accumulation and translocation (Haque et al., 2008). In order for a plant growing on contaminated soil to avoid metal toxicity, sequestering the metal in the root serves as an appropriate metal exclusion strategy (Marques et al., 2009). There is evidence of plant mechanisms which allow roots to accumulate high levels of trace metals as compared with other plant parts (MacFarlane et al., 2003; Naidoo et al., 2014). This phenomenon was detected in mangrove species such as Avicennia marina, Rhizophora spp., and Kandelia spp. (Peters et al., 1997) and is consistent with data for the present study (except for Mn). Several reports have shown that fine roots of mangrove plants accumulate high trace metal concentrations; however, the extent of accumulation depends upon plant mechanisms and sediment chemistry (Chaudhuri et al., 2014).

Aerial roots of mangrove plants diffuse oxygen into the substrate such that oxidation occurs in the rhizosphere, resulting in metal accumulation in fine roots (Chaudhuri et al., 2014; Machado et al., 2005; Marchand et al., 2011). The large surface area and high density of the root system may encourage metal uptake, along with adsorption of metals subsequent to oxidation of metal sulphides (Lacerda et al., 1992, 1993; Marchand et al., 2011; Otero et al., 2006). Highest TF values were found in stems of D. trifoliata (9.3 and 7.9 for $\mathrm{Mn}$ and $\mathrm{Pb}$, respectively). Plants with $\mathrm{TF}$ values $>1$ have a high efficiency of translocation of metals from roots to aboveground parts (Murray et al., 2009).

Among 334 plant tissue samples, high capacities for metal absorption from sediments to plant tissue (i.e., BCF values > 1) were expressed in 285 plant organs, while low BCF values were found in 49 plant organs (Table 5). In this study, BCF values of leaves ranged from 0.4-9.0 for $\mathrm{Cu}, 1.6-16.0$ for $\mathrm{Zn}, 3.9-28.3$ for $\mathrm{Ni}, 0.2-8.3$ for $\mathrm{Mn}, 0.7-65.1$ for $\mathrm{Cr}, 0.2-24.0$ for $\mathrm{Cd}$, and 0.2-22.7 for $\mathrm{Pb}$, respectively. $\mathrm{BCF}$ values for stems ranged from 0.5-12.2 for $\mathrm{Cu}, 3.4-19.3$ for $\mathrm{Zn}, 4.8-22.4$ for $\mathrm{Ni}, 0.3-16.4$ for $\mathrm{Mn}$, 0.7-52.0 for $\mathrm{Cr}$, 0.4-23.7 for $\mathrm{Cd}$, and 0.1-26.7 for $\mathrm{Pb}$, respectively, and $\mathrm{BCF}$ values for roots ranged from 0.2-36.9 for $\mathrm{Cu}, 5.7-30.9$ for $\mathrm{Zn}, 3.1-29.5$ for $\mathrm{Ni}, 0.4-24.8$ for $\mathrm{Mn}$, 0.7-115.2 for $\mathrm{Cr}, 0.6-21.8$ for $\mathrm{Cd}$, and 0.2-30.2 for $\mathrm{Pb}$, respectively. High $\mathrm{BCF}$ values were noted for many metals in roots; in particular, highest $\mathrm{BCF}$ values for $\mathrm{Cu}, \mathrm{Zn}, \mathrm{Ni}$ and $\mathrm{Cr}$ were in roots of I. pes-caprae, while highest $\mathrm{BCF}$ values for $\mathrm{Mn}$ and $\mathrm{Pb}$ were in T. angustifolia. The highest $\mathrm{BCF}$ value for Cd was in leaves of I. pes-caprae. 
Table 4. Translocation factor for mangrove plant parts. $(n=3)$

\begin{tabular}{|c|c|c|c|c|c|c|c|c|}
\hline \multirow[t]{2}{*}{ Plant } & \multirow[t]{2}{*}{ Tissue } & \multicolumn{7}{|c|}{ TF } \\
\hline & & $\mathbf{C u}$ & $\mathbf{Z n}$ & $\mathrm{Ni}$ & Mn & $\mathrm{Cr}$ & $\mathbf{C d}$ & $\mathbf{P b}$ \\
\hline \multirow[t]{2}{*}{ W. biflora } & Stem & $0.5 \pm 0.0$ & $1.1 \pm 0.1$ & $1.6 \pm 0.3$ & $0.4 \pm 0.0$ & $1.8 \pm 0.1$ & $1.2 \pm 0.1$ & $2.0 \pm 0.1$ \\
\hline & Leaf & $0.5 \pm 0.0$ & $0.7 \pm 0.1$ & $1.3 \pm 0.4$ & $1.0 \pm 0.0$ & $1.1 \pm 0.1$ & $1.3 \pm 0.1$ & $0.5 \pm 0.1$ \\
\hline \multirow{2}{*}{ S. portulacastrum } & Stem & $2.1 \pm 0.2$ & $1.3 \pm 0.1$ & $1.3 \pm 0.1$ & $0.5 \pm 0.0$ & $1.0 \pm 0.2$ & $0.9 \pm 0.4$ & $0.4 \pm 0.1$ \\
\hline & Leaf & $1.0 \pm 0.1$ & $1.1 \pm 0.2$ & $1.1 \pm 0.3$ & $0.7 \pm 0.1$ & $1.0 \pm 0.1$ & $1.3 \pm 0.6$ & $0.2 \pm 0.0$ \\
\hline \multirow[t]{2}{*}{ I. pes-caprae } & Stem & $0.2 \pm 0.0$ & $0.1 \pm 0.0$ & $0.4 \pm 0.0$ & $0.1 \pm 0.0$ & $2.9 \pm 0.3$ & $1.1 \pm 0.2$ & $4.1 \pm 0.6$ \\
\hline & Leaf & $0.2 \pm 0.0$ & $0.2 \pm 0.1$ & $0.5 \pm 0.1$ & $0.2 \pm 0.0$ & $3.5 \pm 0.0$ & $1.1 \pm 0.1$ & $5.9 \pm 1.2$ \\
\hline \multirow[t]{2}{*}{ P. nodiflora } & Stem & $0.6 \pm 0.0$ & $1.1 \pm 0.0$ & $1.0 \pm 0.2$ & $0.5 \pm 0.0$ & $0.5 \pm 0.1$ & $0.5 \pm 0.1$ & $1.2 \pm 0.1$ \\
\hline & Leaf & $0.3 \pm 0.0$ & $0.8 \pm 0.0$ & $0.8 \pm 0.2$ & $0.3 \pm 0.0$ & $0.3 \pm 0.1$ & $0.4 \pm 0.1$ & $-{ }^{1}$ \\
\hline \multirow[t]{2}{*}{ D. trifoliata } & Stem & $0.9 \pm 0.1$ & $1.3 \pm 0.2$ & $1.2 \pm 0.1$ & $9.3 \pm 0.6$ & $2.3 \pm 0.6$ & $0.5 \pm 0.1$ & $7.9 \pm 0.2$ \\
\hline & Leaf & $0.5 \pm 0.1$ & $0.9 \pm 0.2$ & $0.9 \pm 0.1$ & $8.7 \pm 0.6$ & $2.0 \pm 0.5$ & $0.4 \pm 0.1$ & $8.9 \pm 0.2$ \\
\hline \multirow[t]{2}{*}{ P. foetida } & Stem & $0.7 \pm 0.0$ & $1.1 \pm 0.2$ & $0.9 \pm 0.0$ & $1.8 \pm 0.2$ & $0.9 \pm 0.1$ & $0.6 \pm 0.1$ & $0.9 \pm 0.1$ \\
\hline & Leaf & $0.5 \pm 0.0$ & $0.9 \pm 0.1$ & $0.7 \pm 0.0$ & $1.4 \pm 0.1$ & $0.7 \pm 0.1$ & $0.5 \pm 0.1$ & $0.7 \pm 0.1$ \\
\hline \multirow[t]{2}{*}{ D. caricosum } & Stem & $0.3 \pm 0.0$ & $0.7 \pm 0.0$ & $0.9 \pm 0.0$ & $0.4 \pm 0.0$ & $0.4 \pm 0.0$ & $1.2 \pm 0.4$ & $0.2 \pm 0.0$ \\
\hline & Leaf & - & - & - & - & - & - & - \\
\hline \multirow[t]{2}{*}{ P. karka } & Stem & $0.7 \pm 0.2$ & $1.1 \pm 0.1$ & $0.8 \pm 0.1$ & $0.1 \pm 0.0$ & $0.6 \pm 0.1$ & $0.8 \pm 0.1$ & $0.1 \pm 0.0$ \\
\hline & Leaf & $0.4 \pm 0.1$ & $1.4 \pm 0.1$ & $0.9 \pm 0.0$ & $0.3 \pm 0.0$ & $1.5 \pm 0.1$ & $0.2 \pm 0.0$ & $0.2 \pm 0.0$ \\
\hline \multirow[t]{2}{*}{ A. marina } & Stem & $0.9 \pm 0.2$ & $0.7 \pm 0.1$ & $0.8 \pm 0.2$ & $0.3 \pm 0.0$ & $0.8 \pm 0.1$ & $0.8 \pm 0.2$ & $0.8 \pm 0.0$ \\
\hline & Leaf & $1.1 \pm 0.2$ & $0.6 \pm 0.1$ & $1.5 \pm 0.3$ & $1.8 \pm 0.2$ & $0.4 \pm 0.1$ & $1.1 \pm 0.1$ & $0.4 \pm 0.0$ \\
\hline \multirow[t]{2}{*}{ A. ebracteatus } & Stem & $0.5 \pm 0.0$ & $1.3 \pm 0.1$ & $1.1 \pm 0.1$ & $1.2 \pm 1.5$ & $0.7 \pm 0.0$ & $1.1 \pm 0.1$ & $1.9 \pm 0.1$ \\
\hline & Leaf & - & - & - & - & - & - & - \\
\hline \multirow[t]{2}{*}{ A. alba } & Stem & $2.7 \pm 0.4$ & $1.1 \pm 0.2$ & $1.0 \pm 0.0$ & $0.5 \pm 0.0$ & $1.9 \pm 0.4$ & $1.6 \pm 0.3$ & $0.2 \pm 0.1$ \\
\hline & Leaf & $2.2 \pm 0.4$ & $0.7 \pm 0.2$ & $0.7 \pm 0.0$ & $0.5 \pm 0.0$ & $2.0 \pm 0.4$ & $2.1 \pm 0.4$ & $0.4 \pm 0.1$ \\
\hline \multirow[t]{2}{*}{ P. indica } & Stem & $0.9 \pm 0.2$ & $1.3 \pm 0.0$ & $0.8 \pm 0.4$ & $0.4 \pm 0.0$ & $1.5 \pm 0.1$ & $0.9 \pm 0.2$ & - \\
\hline & Leaf & $1.3 \pm 0.3$ & $2.5 \pm .02$ & $1.2 \pm 0.1$ & $2.4 \pm 0.2$ & $1.3 \pm 0.1$ & $1.9 \pm 0.1$ & $0.3 \pm 0.0$ \\
\hline \multirow{2}{*}{ T. populnea } & Stem & $4.4 \pm 0.5$ & $1.6 \pm 0.0$ & $1.1 \pm 0.2$ & $0.7 \pm 0.0$ & $1.2 \pm 0.3$ & $0.8 \pm 0.1$ & $0.5 \pm 0.0$ \\
\hline & Leaf & $1.2 \pm 0.4$ & $1.7 \pm 0.1$ & $1.4 \pm 0.1$ & $1.9 \pm 0.3$ & $2.6 \pm 0.4$ & $0.7 \pm 0.0$ & $0.3 \pm 0.0$ \\
\hline \multirow[t]{2}{*}{ R. mucronata } & Stem & $0.3 \pm 0.0$ & $0.5 \pm 0.1$ & $1.1 \pm 0.2$ & $1.1 \pm 0.0$ & $1.2 \pm 0.2$ & $0.9 \pm 0.0$ & $1.4 \pm 0.2$ \\
\hline & Leaf & $0.2 \pm 0.0$ & $0.2 \pm 0.1$ & $0.8 \pm 0.1$ & $1.1 \pm 0.0$ & $1.3 \pm 0.2$ & $0.8 \pm 0.0$ & $1.6 \pm 0.3$ \\
\hline \multirow[t]{2}{*}{ T. angustifolia } & Stem & $0.3 \pm 0.1$ & $0.6 \pm 0.1$ & $0.6 \pm 0.1$ & $0.7 \pm 0.0$ & $2.0 \pm 0.1$ & $0.7 \pm 0.0$ & $0.2 \pm 0.0$ \\
\hline & Leaf & - & - & - & - & - & - & - \\
\hline \multirow[t]{2}{*}{ E. dulcis } & Stem & $0.3 \pm 0.1$ & $0.6 \pm 0.0$ & $0.9 \pm 0.1$ & $0.7 \pm 0.1$ & $0.8 \pm 0.2$ & $1.1 \pm 0.2$ & $0.7 \pm 0.1$ \\
\hline & Leaf & - & - & - & - & - & - & - \\
\hline \multirow[t]{2}{*}{ C. involucratus } & Stem & $0.6 \pm 0.1$ & $1.1 \pm 0.2$ & $1.1 \pm 0.2$ & $0.5 \pm 0.0$ & $3.5 \pm 0.6$ & $1.3 \pm 0.6$ & $0.2 \pm 0.0$ \\
\hline & Leaf & - & - & - & - & - & - & - \\
\hline \multirow[t]{2}{*}{ A. aureum } & Stem & $0.6 \pm 0.0$ & $0.9 \pm 0.1$ & $0.9 \pm 0.1$ & $0.2 \pm 0.0$ & $0.7 \pm 0.1$ & $0.6 \pm 0.1$ & $0.3 \pm 0.0$ \\
\hline & Leaf & - & - & - & - & - & - & - \\
\hline
\end{tabular}

${ }^{1}=$ Data not available.

Several mangrove species may be categorized as accumulators as they have TF and $\mathrm{BCF}$ values $>1$ (e.g., T. populnea for $\mathrm{Ni}$ and $C$. involucratus for $\mathrm{Cr}$ ). Many species in this study are classified as excluder plants for metals as they have $\mathrm{TF}<1$ and $\mathrm{BCF}>1$ (C. involucratus for $\mathrm{Cu}$, I. pes-caprae for $\mathrm{Zn}$, T. angustifolia for $\mathrm{Mn}$, and $P$. karka for $\mathrm{Pb})$.

The root systems of mangrove species reduce soil erosion and may stabilize metals within coastal sediments. In this investigation, $T$. angustifolia, a monocot present in mangrove areas in Thailand, possess an extensive root distribution in both vertical and horizontal planes (Yen and Saibeh, 2013). It also has excluder potential for $\mathrm{Cu}$. Thus, this grass species can reduce soil erosion and stabilize metals simultaneously.

For successful phytoextraction, plant biomass production must be considered. In some cases, mangrove plants may have high potential for phytoremediation even if tissue metal levels are relatively modest; a high biomass producer still has potential for significant metal removal from soil. 
Table 5. Bioconcentration factor for mangrove plant parts. $(n=3)$

\begin{tabular}{|c|c|c|c|c|c|c|c|c|}
\hline \multirow[t]{2}{*}{ Plant } & \multirow[t]{2}{*}{ Tissue } & \multicolumn{7}{|c|}{ BCF } \\
\hline & & $\mathrm{Cu}$ & Zn & $\mathbf{N i}$ & Mn & $\mathrm{Cr}$ & Cd & $\mathbf{P b}$ \\
\hline \multirow{3}{*}{ W. biflora } & Stem & $1.2 \pm 0.1$ & $8.5 \pm 0.3$ & $5.9 \pm 1.0$ & $0.5 \pm 0.1$ & $2.6 \pm 0.1$ & $10.5 \pm 0.7$ & $2.1 \pm 0.0$ \\
\hline & Leaf & $1.3 \pm 0.0$ & $6.0 \pm 0.8$ & $4.8 \pm 1.5$ & $1.1 \pm 0.2$ & $1.6 \pm 0.1$ & $11.5 \pm 0.5$ & $0.5 \pm 0.0$ \\
\hline & Root & $2.5 \pm 0.0$ & $8.1 \pm 0.6$ & $3.8 \pm 0.1$ & $1.1 \pm 0.1$ & $1.5 \pm 0.0$ & $9.0 \pm 0.5$ & $1.0 \pm 0.0$ \\
\hline \multirow[t]{3}{*}{ S. portulacastrum } & Stem & $2.6 \pm 0.3$ & $9.2 \pm 0.1$ & $13.9 \pm 0.4$ & $0.4 \pm 0.0$ & $0.9 \pm 0.2$ & $6.1 \pm 1.6$ & $0.9 \pm 0.1$ \\
\hline & Leaf & $1.3 \pm 0.0$ & $8.1 \pm 1.4$ & $11.3 \pm 2.8$ & $0.6 \pm 0.1$ & $0.9 \pm 0.1$ & $9.4 \pm 0.2$ & $0.5 \pm 0.0$ \\
\hline & Root & $1.3 \pm 0.1$ & $7.3 \pm 0.2$ & $10.6 \pm 0.8$ & $0.9 \pm 0.1$ & $0.9 \pm 0.0$ & $7.8 \pm 3.1$ & $2.3 \pm 0.5$ \\
\hline \multirow[t]{3}{*}{ I. pes-caprae } & Stem & $0.6 \pm 0.0$ & $3.7 \pm 0.2$ & $7.9 \pm 0.4$ & $1.0 \pm 0.0$ & $43.9 \pm 5.8$ & $15.3 \pm 2.6$ & $2.4 \pm 0.2$ \\
\hline & Leaf & $0.8 \pm 0.1$ & $6.1 \pm 2.3$ & $8.7 \pm 0.2$ & $1.7 \pm 0.2$ & $53.4 \pm 1.9$ & $15.5 \pm 0.8$ & $3.5 \pm 0.3$ \\
\hline & Root & $3.2 \pm 0.1$ & $3.3 \pm 0.6$ & $18.2 \pm 2.6$ & $10.3 \pm 0.9$ & $15.2 \pm 0.6$ & $14.1 \pm 1.7$ & $0.6 \pm 0.1$ \\
\hline \multirow{3}{*}{ P. nodiflora } & Stem & $2.0 \pm 0.1$ & $9.5 \pm 0.0$ & $8.1 \pm 1.3$ & $0.5 \pm 0.0$ & $18.5 \pm 2.1$ & $2.0 \pm 0.6$ & $0.3 \pm 0.0$ \\
\hline & Leaf & $1.2 \pm 0.1$ & $7.3 \pm 0.0$ & $6.4 \pm 1.3$ & $0.2 \pm 0.0$ & $11.4 \pm 2.1$ & $1.7 \pm 0.6$ & $0.4 \pm 0.0$ \\
\hline & Root & $3.4 \pm 0.3$ & $8.8 \pm 0.0$ & $8.3 \pm 0.8$ & $1.0 \pm 0.1$ & $37.7 \pm 1.4$ & $4.3 \pm 0.3$ & -1 \\
\hline \multirow{3}{*}{ D. trifoliata } & Stem & $2.0 \pm 0.2$ & $7.5 \pm 1.3$ & $9.0 \pm 0.3$ & $3.6 \pm 0.3$ & $54.6 \pm 8.5$ & $0.9 \pm 0.1$ & $5.4 \pm 0.3$ \\
\hline & Leaf & $1.3 \pm 0.2$ & $5.3 \pm 1.3$ & $7.3 \pm 0.3$ & $3.4 \pm 0.3$ & $47.6 \pm 8.5$ & $0.8 \pm 0.1$ & $6.1 \pm 0.3$ \\
\hline & Root & $2.3 \pm 0.0$ & $6.0 \pm 0.6$ & $7.8 \pm 0.2$ & $0.4 \pm 0.0$ & $23.9 \pm 2.2$ & $2.0 \pm 0.5$ & $0.7 \pm 0.0$ \\
\hline \multirow[t]{3}{*}{ P. foetida } & Stem & $2.2 \pm 0.1$ & $12.0 \pm 0.3$ & $7.2 \pm 0.2$ & $0.9 \pm 0.1$ & $29.0 \pm 1.5$ & $1.8 \pm 0.2$ & $3.7 \pm 0.1$ \\
\hline & Leaf & $1.4 \pm 0.1$ & $9.9 \pm 0.3$ & $5.5 \pm 0.2$ & $0.7 \pm 0.1$ & $22.0 \pm 1.5$ & $1.6 \pm 0.2$ & $3.1 \pm 0.1$ \\
\hline & Root & $3.1 \pm 0.1$ & $11.5 \pm 1.3$ & $7.8 \pm 0.4$ & $0.5 \pm 0.1$ & $31.0 \pm 3.3$ & $3.1 \pm 0.4$ & $4.3 \pm 0.3$ \\
\hline \multirow[t]{3}{*}{ D. caricosum } & Stem & $1.1 \pm 0.0$ & $4.3 \pm 0.3$ & $7.5 \pm 0.2$ & $4.1 \pm 0.1$ & $31.6 \pm 1.0$ & $5.0 \pm 0.3$ & $1.6 \pm 0.2$ \\
\hline & Leaf & - & - & - & - & - & - & - \\
\hline & Root & $3.3 \pm 0.0$ & $6.2 \pm 0.2$ & $8.8 \pm 0.1$ & $10.2 \pm 0.1$ & $74.5 \pm 4.5$ & $4.7 \pm 1.7$ & $6.9 \pm 0.7$ \\
\hline \multirow[t]{3}{*}{ P. karka } & Stem & $1.6 \pm 0.5$ & $9.9 \pm 0.5$ & $6.2 \pm 0.5$ & $0.4 \pm 0.0$ & $28.6 \pm 6.5$ & $8.8 \pm 2.0$ & $1.2 \pm 0.0$ \\
\hline & Leaf & $1.0 \pm 0.1$ & $12.7 \pm 0.6$ & $6.9 \pm 0.3$ & $1.1 \pm 0.1$ & $68.5 \pm 2.5$ & $2.1 \pm 0.4$ & $2.1 \pm 0.1$ \\
\hline & Root & $2.4 \pm 0.1$ & $9.4 \pm 0.4$ & $7.4 \pm 0.3$ & $3.8 \pm 0.6$ & $46.9 \pm 1.4$ & $10.5 \pm 1.5$ & $9.5 \pm 0.2$ \\
\hline \multirow[t]{3}{*}{ A. marina } & Stem & $1.2 \pm 0.1$ & $5.5 \pm 0.5$ & $6.5 \pm 1.5$ & $1.6 \pm 0.2$ & $11.9 \pm 0.1$ & $7.9 \pm 1.7$ & $8.2 \pm 0.2$ \\
\hline & Leaf & $1.7 \pm 0.1$ & $4.7 \pm 0.3$ & $12.6 \pm 2.1$ & $9.8 \pm 0.9$ & $6.0 \pm 1.5$ & $12.2 \pm 1.2$ & $4.1 \pm 0.1$ \\
\hline & Root & $1.5 \pm 0.3$ & $8.1 \pm 0.6$ & $8.5 \pm 0.5$ & $5.6 \pm 0.2$ & $15.8 \pm 1.8$ & $10.6 \pm 0.7$ & $10.1 \pm 0.1$ \\
\hline \multirow[t]{3}{*}{ A. ebracteatus } & Stem & $1.5 \pm 0.1$ & $8.1 \pm 0.7$ & $6.9 \pm 0.3$ & $2.1 \pm 0.1$ & $22.7 \pm 1.1$ & $14.7 \pm 1.2$ & $6.3 \pm 0.1$ \\
\hline & Leaf & - & - & - & - & - & - & - \\
\hline & Root & $3.0 \pm 0.1$ & $6.2 \pm 0.2$ & $6.5 \pm 0.9$ & $4.8 \pm 3.6$ & $30.9 \pm 2.3$ & $13.7 \pm 0.7$ & $3.4 \pm 0.2$ \\
\hline \multirow[t]{3}{*}{ A. alba } & Stem & $0.5 \pm 0.1$ & $5.7 \pm 0.4$ & $6.5 \pm 0.1$ & $2.7 \pm 0.2$ & $8.5 \pm 0.5$ & $9.2 \pm 0.3$ & $0.1 \pm 0.0$ \\
\hline & Leaf & $0.4 \pm 0.1$ & $3.6 \pm 0.5$ & $4.8 \pm 0.2$ & $2.5 \pm 0.3$ & $9.2 \pm 0.5$ & $12.0 \pm 0.3$ & $0.2 \pm 0.0$ \\
\hline & Root & $0.2 \pm 0.0$ & $5.5 \pm 0.5$ & $6.6 \pm 0.2$ & $4.9 \pm 0.6$ & $4.7 \pm 0.8$ & $6.0 \pm 1.2$ & - \\
\hline \multirow{3}{*}{ P. indica } & Stem & $2.3 \pm 0.4$ & $6.9 \pm 0.2$ & $5.4 \pm 2.4$ & $0.3 \pm 0.0$ & $8.8 \pm 0.3$ & $6.8 \pm 1.1$ & $0.5 \pm 0.0$ \\
\hline & Leaf & $3.5 \pm 0.6$ & $13.9 \pm 1.3$ & $7.9 \pm 0.5$ & $1.8 \pm 0.1$ & $7.5 \pm 0.4$ & $15.5 \pm 0.3$ & $0.4 \pm 0.0$ \\
\hline & Root & $2.7 \pm 0.2$ & $5.5 \pm 0.3$ & $6.8 \pm 0.2$ & $0.7 \pm 0.0$ & $5.7 \pm 0.1$ & $8.0 \pm 0.2$ & $1.3 \pm 0.1$ \\
\hline \multirow[t]{3}{*}{ T. populnea } & Stem & $3.0 \pm 0.1$ & $9.6 \pm 0.3$ & $15.8 \pm 0.4$ & $0.3 \pm 0.1$ & $8.5 \pm 0.6$ & $4.9 \pm 0.6$ & $1.5 \pm 0.2$ \\
\hline & Leaf & $0.9 \pm 0.2$ & $10.1 \pm 0.4$ & $20.8 \pm 1.6$ & $1.0 \pm 0.1$ & $18.4 \pm 1.0$ & $4.3 \pm 0.2$ & $0.9 \pm 0.0$ \\
\hline & Root & $0.7 \pm 0.1$ & $5.9 \pm 0.2$ & $14.7 \pm 2.0$ & $0.5 \pm 0.1$ & $7.2 \pm 1.3$ & $5.9 \pm 0.2$ & $2.9 \pm 0.1$ \\
\hline \multirow[t]{3}{*}{ R. mucronata } & Stem & $0.7 \pm 0.0$ & $3.3 \pm 0.4$ & $7.1 \pm 0.1$ & $11.3 \pm 0.3$ & $20.3 \pm 0.7$ & $2.2 \pm 0.2$ & $0.8 \pm 0.1$ \\
\hline & Leaf & $0.6 \pm 0.0$ & $1.2 \pm 0.4$ & $5.4 \pm 0.2$ & $11.2 \pm 0.3$ & $21.8 \pm 0.7$ & $1.9 \pm 0.2$ & $0.9 \pm 0.1$ \\
\hline & Root & $2.6 \pm 0.1$ & $6.6 \pm 0.7$ & $6.8 \pm 0.9$ & $10.1 \pm 0.3$ & $17.2 \pm 2.8$ & $2.4 \pm 0.2$ & $0.6 \pm 0.1$ \\
\hline T. angustifolia & Stem & $0.3 \pm 0.1$ & $7.1 \pm 0.1$ & $10.1 \pm 0.6$ & $9.3 \pm 0.5$ & $39.4 \pm 0.9$ & $8.8 \pm 0.6$ & $0.7 \pm 0.1$ \\
\hline & Leaf & - & - & - & - & - & - & - \\
\hline & Root & $0.9 \pm 0.0$ & $12.3 \pm 1.6$ & $16.9 \pm 1.0$ & $14.1 \pm 0.0$ & $19.5 \pm 0.5$ & $13.0 \pm 0.0$ & $4.6 \pm 0.1$ \\
\hline E. dulcis & Stem & $1.2 \pm 0.2$ & $6.9 \pm 0.5$ & $6.9 \pm 0.5$ & $1.9 \pm 0.3$ & $28.4 \pm 5.5$ & $7.3 \pm 0.8$ & $1.7 \pm 0.3$ \\
\hline & Leaf & - & - & - & - & - & - & - \\
\hline & Root & $3.6 \pm 0.2$ & $10.7 \pm 0.3$ & $7.6 \pm 0.5$ & $2.9 \pm 0.3$ & $36.5 \pm 7.1$ & $6.5 \pm 1.5$ & $2.5 \pm 0.1$ \\
\hline C. involucratus & Stem & $2.9 \pm 0.4$ & $10.0 \pm 1.0$ & $7.2 \pm 0.3$ & $3.5 \pm 0.1$ & $91.8 \pm 4.2$ & $3.6 \pm 1.1$ & $1.8 \pm 0.1$ \\
\hline & Leaf & - & - & - & - & - & - & - \\
\hline & Root & $4.6 \pm 0.1$ & $9.0 \pm 1.5$ & $6.9 \pm 1.5$ & $7.1 \pm 0.3$ & $27.1 \pm 4.9$ & $2.9 \pm 0.7$ & $9.4 \pm 0.2$ \\
\hline A. aureum & Stem & $3.6 \pm 0.1$ & $10.7 \pm 0.4$ & $7.5 \pm 0.5$ & $0.2 \pm 0.0$ & $27.1 \pm 2.3$ & $1.0 \pm 0.1$ & $0.8 \pm 0.0$ \\
\hline & Leaf & - & - & - & - & - & - & - \\
\hline & Root & $6.4 \pm 0.2$ & $12.1 \pm 1.4$ & $8.4 \pm 1.0$ & $1.0 \pm 0.1$ & $41.5 \pm 6.1$ & $1.8 \pm 0.2$ & $2.9 \pm 0.2$ \\
\hline
\end{tabular}

${ }^{1}=$ Data not available.

\section{Conclusions}

Mangrove plant species in Pattani Bay, Thailand were assessed as a biological tool for remediation and reduction of metal mobility in sediments. Pattani Bay is an important region for aquaculture and as a nursery for numerous marine organisms; however, this area has received large quantities of anthropogenic contaminants, particularly metals from domestic and industrial sources. Investigation of metal 
behavior in mangrove sediments and plants is important for clarifying the ability of mangroves to treat soil contamination. In the current study, mangrove plant species generally accumulated low concentrations of metals. However, some species demonstrated the potential for metal phytostabilization or phytoextraction. Given that mangrove shrub species have a long life span, produce high biomass and possess an extensive root system, we suggest that these species be used for stabilization of metals in mangrove ecosystems.

Phytoremediation may be an optimal remediation option in metal-contaminated coastal sediments; this is an effective solar-driven and low-cost technology which uses native plants for metal immobilization or extraction. Furthermore, this technology does not require addition of fertilizer (which increases treatment costs), and does not produce secondary wastes that require further treatment (Cunningham et al., 1995; Prasad, 2003); it is therefore an environmentally benign technology which does not alter local soil properties.

Acknowledgement. This research was financially supported by a grant from the SAT ASEAN Scholarship (Grant No.5604) at Prince of Songkla University, Pattani Campus.

\section{REFERENCES}

[1] Aksornkoae, S. (1993): Ecology and management of mangroves. - IUCN, Bangkok, Thailand.

[2] Aksornkoae, S., Maxell, G. S., Havanond, S., Panichsuko, S. (1992): Plants in mangroves. - Chalongrat Co., Ltd., Bangkok, Thailand.

[3] Allen, S. E., Grimshaw, H. M., Parkinson, H. M., Quarmby, J. A. (1974): Chemical analysis of ecological materials. - Blackwell, Oxford.

[4] Anouti, F. A. (2014): Bioaccumulation of heavy metals within mangrove ecosystems. Biodiversity and Endangered species 2(2): 1-2.

[5] APHA/AWWA/WEF. (2005): Standard methods for the examination of water and wastewater. - APHA, 21 st edition, Washington, DC.

[6] Baker, A. J. M. (1981): Accumulators and excluders-strategies in the response of plants to heavy metals. - Journal of Plant Nutrition 3: 643-654.

[7] Banerjee, J., Senthilkumar, B., Purvaja, R., Ramesh, R. (2012): Sedimentation and trace metal distribution in selected locations of Sundarbans mangroves and Hooghly estuary, northeast coast of India. - Environmental Geochemistry and Health 34: 27-42.

[8] Black, G. R. (1965): Bulk density: method of soil analysis. Monograph No. 9 Part I. American Society of Agronomy Inc., Washington, DC.

[9] Branquinho, C., Serrano, H. C., Pinto, M. J., Martins-Loucao, M. A. (2007): Revisiting the Plant Hyperaccumulation Criteria to Rare Plants and Earth Abundant Elements. Environmental Pollution (14): 437-443.

[10] Bray, R. H., Kurtz, L. T. (1945): Determination of total, organic and available forms of phosphorus in soil. - Soil Science 59: 39-45.

[11] Chaudhuri, P., Nath, B., Birch, G. (2014): Accumulation of trace metals in grey mangrove Avicennia marina fine nutritive roots: The role of rhizosphere processes. Marine Pollution Bulletin 79: 284-292.

[12] Chakraborty, P., Babu, P. V. R., Sarma, V. V. (2012): A study of lead and cadmium speciation in some estuarine and coastal sediments. - Chemical Geology 294-295: 217225.

[13] Cheewasedtham,W., Hasamoh, M., Chairattanamanokorn, W., Pengpara, U., Suwan-in, A., Krisonpornson, B., Cheewasedtham, C., Tjell, J. C. (2003): The Strategy Plan for 
Control and Rehabilitation of Lead Contamination in Pattani River. - Research meeting report, Prince of Songkla University, Pattani, Thailand.

[14] Chen, S. B., Zhu, Y. G., Hu, Q. H. (2005): Soil to plant transfer of 238U, 226Ra and 232Th on a uranium-impacted soil from southeastern China. - Journal of Environmental Radioactivity 82: 223-236.

[15] Chowdhury, R., Favas, P. J. C., Pratas, J., Jonathan, M. P., Ganesh, P. S., Sarkar, S. K. (2015): Accumulation of trace metals by mangrove plants in Indian Sundarban wetland: Prospects for phytoremediation. - International Journal of Phytoremediation 17: 885-894.

[16] Cowan, C. E., Zachara, J. M., Smith, S. C., Resch, C. T. (1992): Individual sorbent contributions to cadmium sorption on ultisols of mixed mineralogy. - Soil Science Society of America Journal 56: 1084-1094.

[17] Cunningham, S. D., Berti, W. R., Huang, J. W. (1995): Remediation of contaminated soils and sludges by green plants. - In: Hinchee, R. E., Means, J. L., Burris, D. R. (eds.) Bioremediation of inorganics, Battelle Press, Columbus, $\mathrm{OH}$.

[18] Greger, M. (2004): Metal availability, uptake, transport and accumulation in plants. - In: Prasad, M. N. V. (ed.) Heavy Metal Stress in Plants: From biomolecules to ecosystems, Springer, Berlin.

[19] Gohre, V., Paszkowski, U. (2006): Contribution of the arbuscular mycorrhizal symbiosis to heavy metal phytoremediation. - Planta 223: 1115-1122.

[20] Ghosh, M., Singh, S. P. (2005): A review on phytoremediation of heavy metals and utilization of its by products. - Applied Ecology and Environmental Research 3(1): 1-18.

[21] Hajisamae, S., Yeesin, P. (2014): Do habitat, month and environmental parameters affect shrimp assemblage in a shallow semi-enclosed tropical bay, Thailand?. - Raffles Bulletin of Zoology 62: 107-114.

[22] Hajisamae, S., Yeesin, P., Chaimongkol, S. (2006): Habitat utilization by fishes in a shallow, semi-enclosed estuarine bay in southern Gulf of Thailand. - Estuarine, Coastal and Shelf Science 68: 647-655.

[23] Haque, N., Peralta-Videa, J. R., Jones, G. L., Gill, T. E., Gardea-Torresdey, J. L. (2008): Screening the phytoremediation potential of desert broom (Baccharis sarothroides Gray) growing on mine tailings in Arizona, USA. - Environmental Pollution 153: 362-368.

[24] Harty, C. (1997): Mangroves in New South Wales and Victoria. - Vista Publications, Melbourne, Australia.

[25] Harbison, P. (1986): Mangrove muds-a sink and source for trace metals. - Marine Pollution Bulletin 17: 273-276.

[26] Kapi, C., Patient, G., Nelly, K., Patrick, E. A., Rodrigue, A. (2011): Evaluation of heavy metals pollution of Nokoue Lake. - African Journal of environmental science and technology 5(3): 255-261.

[27] Kim, K. T., Kim, E. S., Cho, S. R., Park, J. K., Ra, K. T., Lee, J. M. (2010): Distribution of heavy metals in the environmentals samples of the Saemangeum coastal area, Korea. Coastal, Environmental and Ecosystem 71-90.

[28] Lacerda, L. D. (1997): Trace metals in mangrove plants: Why such low concentrations?. In: Kjerfve, B., Lacerda, L. D., Diop, H. S. (eds.) Mangrove ecosystem studies in Latin America and Africa, Unesco, Paris.

[29] Lacerda, L. D., Fernandez, M. A., Calazans, C. F., Tanizaki, K. F. (1992): Bioavailability of heavy metals in sediments of two coastal lagoons in Rio de Janeiro, Brazil. Hydrobiologia 228: 65-70.

[30] Lacerda, L. D., Carvalho, C. E. V., Tanizaki, K. F., Ovalle, A. R. C., Rezende, C. E. (1993): The biogeochemistry and trace metals distribution of mangrove rhizospheres. Biotropica 25: 252-257.

[31] Lyimo, T. J., Pol, A., Op den Camp, H. J. M. (2002): Methane emission, sulphide concentration and redox potential profiles in Mtoni mangrove sediment, Tanzania. Western Indian Ocean Journal of Marine Science 1(1): 71-80. 
[32] MacFarlane, G. R., Pulkownik, A., Burchett, M. D. (2003): Accumulation and distribution of heavy metals in the grey mangrove, Avicennia marina (Forsk.) Vierh: Biological indication potential. - Environmental Pollution 123: 139-151.

[33] Machado, W., Gueiros, B. B., Lisboa-Filho, S. D., Lacerdo, L. D. (2005): Trace metals in mangrove seedlings: role of iron plaque formation. - Wetlands Ecology and Management 13: 199-206.

[34] Machado, W., Silva-Filho, E. V., Oliveira, R. R., Lacerda, L. D. (2002): Trace metal retention in mangrove ecosystems in Guanabara Bay, SE Brazil. - Marine Pollution Bulletin 44: 1277-1280.

[35] MadejÓn, P., Murillo, J. M., MarañÓn, T., Cabrera, F., Soriano, M. A. (2003): Trace element and nutrient accumulation in sunflower plants two years after the Aznalcollar mine spill. - Science of the Total Environment 307: 239-57.

[36] Marchand, C., Allenbach, M., Lallier-Vergès, E. (2011): Relationships between heavy metals distribution and organic matter cycling in mangrove sediments (Conception Bay, New Caledonia). - Geoderma 160: 444-456.

[37] Marschner, H. (1986): Mineral nutrition of higher plants. - Academic Press, London.

[38] Marques, A. P. G. C., Rangel, A. O. S. S., Castro, P. M. L. (2009): Remediation of heavy metal contaminated soils: phytoremediation as a potentially promising clean-up technology. - Critical Reviews in Environmental Science and Technology 39: 622-654.

[39] Meeinkuirt, W., Kruatrachue, M., Tanhan, P., Chaiyarat, R., Pokethitiyook, P. (2013): Phytostabilization potential of $\mathrm{Pb}$ mine tailings using by two grass species, Thysanolaena maxima and Vetiveria zizanioides. - Water, Air, and Soil Pollution 224: 1750-1782.

[40] Meeinkuirt, W., Pokethitiyook, P., Kruatrachue, M., Tanhan, P., Chaiyarat, R. (2012): Phytostabilization of lead by various tree species using pot and field trial experiments. International Journal of Phytoremediation 14(9): 925-938.

[41] Moreira, I. T. A., Oliveira, O. M. C., Triguis, J. A., Queiroz, A. F. S., Ferreira, S. L. C., Martin, C. M. S., Silva, A. C. M., Falcão, B. A. (2013): Phytoremediation in mangrove sediments impacted by persistent total petroleum hydrocarbons (TPH's) using Avicennia schaueriana. - Marine Pollution Bulletin 67: 130-136.

[42] Murray, H., Thompson, K., Macfie, S. M. (2009): Site- and species-specific patterns of metal bioavailability in edible plants. - Botany 87: 702-711.

[43] Naidoo, G., Hiralal, T., Naidoo, Y. (2014): Ecophysiological response of the mangrove Avicennia marina to trace metal contamination. - Flora 209: 63-72.

[44] Otero, X. L., Ferreira, T. O., Vida-Torrado, P., Macias, F. (2006): Spatial variation in pore water geochemistry in a mangrove system (Pai Matos island, Cananeia-Brazil). Applied Geochemistry 21: 2171-2186.

[45] Panfili, F., Manceau, A., Sarret, A., Spadini, L., Kirpichchikova, T., Bert, V., Laboudigue, A., Marcus, M. A., Ahamdach, N., Libert, M. (2005): The effect of phytostabilization on $\mathrm{Zn}$ speciation in a dredged contaminated sediment using scanning electron microscopy, X-ray fluorescence, EXAFS spectroscopy, and principal component analysis. - Geomichica et Cosmochimica Acta 69(9): 2265-2284.

[46] Pahalawattaarachchi, V., Purushothaman, C. S., Venilla, A. (2009): Metal phytoremediation potential of Rhizophora mucronata (Lam.). - Indian Journal of Marince Science 38(2): 178-183.

[47] Paz-Alberto, A. M., Sigua, G. C. (2013): Phytoremediation: A green technology to remove environmental pollutants. - American Journal of Climate Change 2: 71-86.

[48] Peters, E. C., Gassman, N. J., Firman, J. C., Richmond, R. H., Power, E. A. (1997): Ecotoxicology of tropical marine ecosystems. - Environmental Toxicology and Chemistry 16: 12-40.

[49] Phaenark, J., Pokethiyook, P., Kruatrachue, M., Ngernsansaruay, C. (2009): Cd and Zn accumulation in plants from the Padaeng zinc mine area. - International Journal of Phytoremediation 11: 479-495. 
[50] Pichtel, J. 2007. Fundamentals of Site Remediation for Metal- and HydrocarbonContaminated Soils. - Government Institutes, Inc., Rockville, MD.

[51] Plathong, J., Sitthirach, N. (1998): Traditional and current use of mangrove forest in Southern Thailand. - Publication No.3, Wetlands International Thailand Programme/PSU, $91 \mathrm{pp}$.

[52] Prasad, M. N. V. (2003): Phytoremediation of metal-polluted ecosystem: Hype for commercialization. - Russian Journal of Plant Physiology 50(5): 686-700.

[53] Ratheesh Kumar, C. S., Joseph, M. M., Gireesh Kumar, T. R., Renjith, K. R., Manju, M. N., Chandramohanakumar, N. (2010): Spatial variability and contamination of heavy metals in the inter-tidal systems of a tropical environment. - International Journal of Environmental Research 4(4): 691-700.

[54] Rezvani, M., Zaefarian, F. (2011): Bioaccumulation and translocation factors of cadmium and lead in Aeluropus littoralis. - Australian Journal Agricultural Engineering 2(4): 114119.

[55] Ruangchuay, R., Lueangthuwapranit, C., Pianthumdee, N. (2007): Apparent characteristics and taxonomic study of macroalgae in Pattani Bay. - Songklanakarin Journal of Science and Technology 29: 893-905.

[56] Sandiyan, S., Thiyagesan, K. (2010): Mangroves-the oceanic woodland. - Science India 13: 1-11.

[57] Sandiyan, S., Kathiresan, K. (2012): Mangrove conservation: a global perspective. Biodiversity and Conservation 21: 3523-3542.

[58] Singh, S. N., Tripathi, R. D. (2007): Environmental bioremediation technologies. Springer, Berlin, Germany.

[59] Sowana, A., Shrestha, R. P., Parkpian, P., Pongquan, S. (2011): Influence of coastal land use on soil heavy-metal contamination in Pattani Bay, Thailand. - Journal of Coastal Research 27(2): 252-262.

[60] Sparks, D. L. (1996): Methods of soil analysis. Part 3. Chemical methods. Book series, No.5. - Soil Science Society of America, Wisconsin.

[61] Stokes, D. J., Harris, R. J. (2015): Sediment properties and surface erodibility following a large-scale mangrove (Avicennia marina) removal. - Continental Shelf Research 107: 110 .

[62] Swennen, C., Moolenbeek, R. G., Ruttanadakul, N., Hobbelink, H., Bekker, H., Hajisamae, S. (2001): The molluscs of the southern Gulf of Thailand. - Thai Studies in Biodiversity, Bangkok, Thailand.

[63] Suwanjarat, J., Pituksalee, C., Thongchai, S. (2009): Reproductive cycle of Anadara granosa at Pattani Bay and its relationship with metal concentrations in the sediments. Songklanakarin Journal of Science and Technology 31(5): 471-479.

[64] Tam, N. F. Y., Wong, Y. S. (1997): Accumulation and distribution of heavy metals in a simulated mangrove system treated with sewage. - Hydrobiologia 352: 67-75.

[65] Tangahu, B. V., Abdullah, S. R. S., Basri, H., Idris, M., Anuar, N., Mukhlisin, M. (2011): A review on heavy metals $(\mathrm{As}, \mathrm{Pb}$, and $\mathrm{Hg}$ ) uptake by plants through phytoremediation. International Journal of Chemical Engineering 21: 1- 31.

[66] Thampanya, U., Vermaat, J., Sinsakul, S. and Panapitukkul, N. (2006): Coastal erosion and mangrove progradation of Southern Thailand. - Estuarine, Coast and Shelf Science 68 (1-2): 75-85.

[67] Turekian, K. K., Wedepohl, K. H. (1961): Distribution of the elements in some major units of the earth's crust. - Geological Society of America Bulletin 72: 175-192.

[68] Usman, A. R. A., Alkredaa, R. S., Wabel, M. I. A. (2013): Heavy metal contamination in sediments and mangroves from the coast of Red Sea: Avicennia marina as potential metal bioaccumulator. - Ecotoxicology and Environmental Safety 97: 263-270.

[69] Walkley, A., Black, C. A. (1934): An examination of degradation method for determining soil organic matter: a proposed modification of the chromic acid titration method. - Soil Science 37: 29-35. 
[70] Xu, S., Lin, C., Qiu, P., Song, Y., Wenhuai, Y., Xu, G., Feng, X., Yang, Q., Yang, X., Niu, A. (2015): Tungsten- and cobalt-dominated heavy metal contamination of mangrove sediments in Shenzhen, China. - Marine Pollution Bulletin. (In Press). http://dx.doi.org/10.1016/j.marpolbul.2015.08.031.

[71] Yen, L. V., Saibeh, K. (2013): Phytoremediation using Typha angustifolia L. for mine water effluent treatment: Case study of ex-mamut copper mine, Ranau, Sabah. - Borneo Science 33: 16-22.

[72] Youssef, T., Saenger, P. (1996): Anatomical adaptive strategies and rhizosphere oxidation in mangrove seedlings. - Australian Journal of Botany 44: 297-313.

[73] Zhang, R., Zhang, F., Ding, Y., Gao, J., Chen, J., Zhou, L. (2013): Historical trends in the anthropogenic heavy metal levels in the tidal flat sediments of Lianyungang, China. Journal of Environmental Sciences 25(7): 1458-1468. 